\title{
PENGEMBANGAN MODUL KIMIA BERBASIS INKUIRI TERBIMBING DISERTAI AYAT-AYAT AL-QUR'AN DAN HADITS PADA MATERI REDUKSI-OKSIDASI UNTUK KELAS X SEMESTER 2 DI SMK BATUR JAYA I CEPER KLATEN
}

\author{
Wulan Widya Kristanti ${ }^{1}$, Sulistyo Saputro ${ }^{2}$, Ashadi $^{3}$ \\ ${ }^{1}$ Program Studi Magister Pendidikan Sains FKIP Universitas Sebelas Maret \\ Surakarta, 57126, Indonesia \\ wulan.w.kristanti@gmail.com \\ ${ }^{2}$ Program Studi Magister Pendidikan Sains FKIP Universitas Sebelas Maret \\ Surakarta, 57126, Indonesia \\ sulistyo68@yahoo.com \\ ${ }^{3}$ Program Studi Magister Pendidikan Sains FKIP Universitas Sebelas Maret \\ Surakarta, 57126, Indonesia \\ mas_ashadi@yahoo.co.id
}

\begin{abstract}
Abstrak
Latar belakang penelitian ini bermula dari minimnya jumlah sumber belajar kimia untuk siswa SMK, adanya dikotomi ilmu pengetahuan dan agama serta model pembelajaran yang masih berpusat pada guru yang identik dengan ceramah, belum adanya modul yang disertai ayat-ayat Al-Qur'an dan Hadits, dan Hasil ulangan harian yang belum memenuhi KKM pada materi reduksi-oksidasi. Tujuan penelitian ini untuk: (1) Pengembangan produk modul kimia berbasis inkuiri terbimbing disertai ayat-ayat Al-Qur'an dan Hadits pada materi reduksi-oksidasi, (2) Mengetahui kelayakan modul kimia berbasis inkuiri terbimbing disertai ayat-ayat Al-Qur'an dan Hadits pada materi reduksi-oksidasi, (3) Mengetahui keefektifan keterterapan modul kimia berbasis inkuiri terbimbing disertai ayat-ayat Al-Qur'an dan Hadits pada materi reduksi-oksidasi. Produk yang dikembangkan dalam penelitian ini adalah modul kimia berbasis inkuiri terbimbing disertai ayat-ayat Al-Qur'an dan Hadits pada materi reduksi-oksidasi. Spesifikasi modul kimia berbentuk media cetak sebagai implementasi kurikulum 2013 berbasis kompetensi. Subjek dalam penelitian ini adalah siswa kelas X SMK Batur Jaya I Ceper, Klaten. Sampel terdiri dari satu kelas pengguna modul dan satu kelas kontrol yang dipilih secara teknik random sampling. Uji reliabilitas menggunakan rumus Kuder Richardson. Sedangkan untuk validitas isi, digunakan formula Aiken. Teknik analisis data yang digunakan ialah deskriptif kualitatif. Kesimpulan dari penelitian ini yaitu; Pertama, Pengembangan modul kimia berbasis inkuiri terbimbing yang disertai ayat-ayat AlQur'an dan Hadits dilakukan dengan menggunakan langkah pengembangan yang kemukakan oleh Borg \& Gall (1983) sampai pada tahap ke sembilan. Kedua, Pengembangan modul kimia berbasis inkuiri terbimbing yang disertai ayat-ayat Al-Qur'an dan Hadits dapat dikatakan "sangat baik" ditinjau dari aspek materi $96,42 \%$, media $92,41 \%$, bahasa $96,64 \%$ dan kegrafisan 98,08\%, sehingga dapat disimpulkan bahwa modul yang dikembangkan dikatakan "sangat baik"untuk digunakan dalam pembelajaran kimia. Ketiga, Pengembangan modul kimia berbasis inkuiri terbimbing yang disertai ayat-ayat Al-Qur'an dan Hadits yang dikembangkan efektif digunakan untuk meningkatkan hasil belajar para siswa. Sehingga dapat disimpulkan bahwa hasil belajar menggunakan modul kimia berbasis inkuiri terbimbing lebih baik dari pembelajaran konvensional.
\end{abstract}

Kata Kunci: Modul, Inkuiri Terbimbing, Reduksi-Oksidasi.

\section{Pendahuluan}

Bahan ajar atau buku penting untuk digunakan dalam proses belajar mengajar karena dengan memiliki bahan ajar memudahkan peserta didik untuk mempelajari suatu kompetensi tertentu secara mandiri. Bahan ajar belum tentu 
harus berasal dari percetakan yang ternama tetapi bisa dikembangkan oleh guru yang bersangkutan sesuai dengan tingkat kebutuhan sekolah masing-masing tanpa harus menyimpang dari silabus yang ada. Hal tersebut selaras dengan Sungkono (2003:1), salah satu kompetensi yang perlu dimiliki seorang guru dalam melaksanakan tugasnya adalah mengembangkan bahan ajar. Pengembangan bahan ajar perlu dilakukan guru agar pembelajaran lebih efektif, efisien, serta sesuai dengan kompetensi yang ingin dicapai. Hal tersebut sesuai dengan Permendiknas nomor 16 tahun 2007 yang mengatur tentang Standar kualifikasi Akademik dan Kompetensi Guru, yaitu bagi guru pada satuan jenjang Sekolah Menengah Atas, baik dalam tuntutan kompetensi pedagogik maupun profesional berkaitan erat dengan kemampuan guru dalam mengembangkan sumber belajar dan bahan ajar (Depdiknas, 2008:1).

Kompetensi mengembangkan bahan ajar idealnya telah dikuasai guru, tetapi pada kenyataannya masih banyak guru yang belum menguasai kompetensi tersebut dengan baik. Guru pada umumnya lebih mengandalkan bahan ajar yang berasal dari penerbit, baik berupa buku ajar ataupun LKS yang berisi latihan soal-soal.

Pembelajaran sains di sekolah pada umumnya dilakukan dengan cara menghafal dan sangat minim dengan kerja/ belajar di laboratorium hal ini dikarenakan tidak adanya fasilitas ruangan laboratorium yang sesuai dengan tingkat kebutuhan, sehingga proses pembelajaran masih banyak dilakukan secara konvensional yaitu dengan metode ceramah. Berdasarkan hasil observasi di SMK Batur Jaya 1 Ceper klaten model pembelajaran yang digunakan adalah pembelajaran yang berpusat pada guru (teacher centered) yang identik dengan ceramah sehingga belum sesuai dengan tujuan kurikulum 2013. Salah satu tujuan dari inti pembelajaran yang berpusat pada peserta didik (student centered) adalah agar peserta didik dapat meningkatkan kemampuan intelek, dapat menyelesaikan masalah secara sistematis, serta dapat mengkomunikasikan ide-ide/ gagasan dalam penulisan atau saat berdiskusi.

Salah satu model pembelajaran yang berpusat pada peserta didik yang dapat dikembangkan sesuai dengan observasi dilakukan adalah inkuiri terbimbing, didalam sintak inkuiri terbimbing siswa diajak untuk dapat menemukan masalahmasalah yang berkaitan dengan materi pelajaran sehingga siswa dapat terlibat secara aktif dalam proses belajar mengajar.

Menurut Sukardjo (2002), rendahnya mutu pendidikan ditunjukkan dengan rendahnya prestasi belajar siswa terutama pada mata pelajaran matematika dan ilmu pengetahuan alam. Salah satu pakar ilmu pengetahuan pendidikan IPA menyatakan bahwa rendahnya mutu pendidikan IPA di Indonesia disebabkan oleh faktor guru, sarana prasarana, faktor kependudukan dan lain-lain. Berdasarkan observasi yang dilakukan dari wawancara pada tahun pelajaran 2013/2014 disemester genap, hasil ulangan harian mata pelajaran kimia materi reduksi-oksidasi masih dominan belum memenuhi standar KKM 70, hal tersebut dibuktikan pada nilai semester yang memiliki nilai rata-rata terendah dari tiga materi yang ada adalah materi reduksi-oksidasi dengan nilai ratarata 72,11 .

Berdasarkan temuan masalah yang terjadi di lapangan maka dapat dikemukakan beberapa masalah pokok dan alternatif solusinya: 1) Minimnya jumlah sumber belajar kimia untuk siswa SMK, 2) Adanya dikotomi ilmu pengetahuan dan agama sehingga kurang mendukung misi Sekolah Menengah Kejuruan yang bercirikan Islam maka alternatif solusi dari kedua point diatas adalah pengintegrasian dari kedua ilmu tersebut yang disajikan dalam bentuk modul, 3) Model pembelajaran yang masih berpusat pada guru yang identik dengan ceramah sehingga belum sesuai dengan tujuan kurikulum 2013, 4) Hasil ulangan harian yang belum memenuhi KKM terdapat pada materi Redoks disebabkan oleh pembelajaran yang 
kurang bermakna dan kurang adanya keinginan dalam berpikir sehingga pengetahuan perlu adanya perbaikan. Dari point 3 dan 4 maka alternatif solusi yang ditawarkan antara lain perlu mengembangkan metode yang lebih menerapkan pembelajaran yang memicu anak untuk berpikir, misalnya dengan pendekatan kontekstual.

Berdasarkan latar belakang masalah di atas maka diperlukan penelitian pengembangan yang meliputi model, media dan modul pembelajaran yang terintegrasikan dengan Islam, namun karena keterbatasan waktu maka peneliti hanya melakukan penelitian pengembangan dengan judul "Pengembangan Modul Kimia Berbasis Inkuiri Terbimbing disertai Ayatayat Al-Qur'an dan Hadits pada Materi Reduksi-Oksidasi untuk Kelas X Semester 2 di SMK Batur Jaya I Ceper Klaten”

\section{Metode Penelitian}

Penelitian ini dilaksanakan di SMK Batur Jaya 1, Klepu, Kecamatan Ceper, Kabupaten Klaten, Provinsi Jawa Tengah, Indonesia. Penelitian dan pengembangan dilaksanakan pada semester genap pada tahun 2014/ 2015, yang secara garis besar dibagi menjadi tiga tahap, yaitu: Pertama, Tahap persiapan, meliputi: permohonan ijin penelitian, survei ke sekolah yang digunakan untuk penelitian, permohonan pembimbing, pengajuan judul penelitian, pembuatan proposal, dan penyusunan instrumen penelitian. Kedua, Tahap penelitian dan pengembangan, meliputi: pengembangan modul Kimia melibatkan para pakar untuk menilai dan memberi masukan dan diujicobakan di semua kegiatan yang berlangsung di lapangan, uji coba instrumen, dan pelaksanaan pengambilan data. Ketiga, Tahap penyelesaian, meliputi: analisis data, pembahasan dan penyusunan laporan penelitian.

Penelitian ini adalah penelitian pengembangan (Research and development) atau disebut dengan penelitian R\&D. Metode ini merupakan metode penelitian yang digunakan untuk menghasilkan produk tertentu dan menguji keefektifan produk tersebut. Langkah pengembangan mengacu pada Borg \& Gall, yang memiliki 10 langkah sebagai berikut: (1) melakukan penelitian dan pengumpulan informasi (Research and information collection) termasuk kajian literatur, observasi kelas, dan membuat kerangka kerja penelitian; (2) melakukan perencanaan (Planning) termasuk tujuan perencanaan, menentukan urutan untuk penelitian; (3) mengembangkan bentuk awal produk (Develop preliminary form of product); (4) melakukan uji lapangan awal/ uji coba kelompok kecil (Preliminary field testing); (5) melakukan revisi terhadap produk utama (Main product revision); (6) melakukan uji lapangan utama (Main field testing); (7) melakukan revisi terhadap produk utama (Operational product revision); (8) melakukan uji lapangan operasional (Operational field testing); (9) melakukan revisi terhadap produk akhir (Final product revision); (10) mendeseminasikan dan mengimplementasikan produk (Dissemination and implememtasion), pada tahap ke sepuluh tidak dilakukan karena membutuhkan waktu yang lama dan tujuan dari penelitian ini sampai pada penyempurnaan produk akhir.

Langkah-langkah penelitian dan pengembangan modul kimia berbasis inkuiri terbimbing yang disertai ayat-ayat Al-qur'an dan Hadits diatas secara rinci dapat dijelaskan sebagai berikut: Pertama, Analisis studi Literatur. Pada tahap penelitian dan pengumpulan informasi dilakukan melalui studi literatur dan studi lapangan. Studi literatur digunakan untuk mengumpulkan berbagai informasi terkait pengembangan modul berbasis inkuiri terbimbing yang disertai Ayat-ayat AlQur'an dan Hadits melalui kajian pustaka dan hasil penelitian yang relevan. Kedua, Analisis studi Lapangan. Studi lapangan dilakukan untuk memperoleh informasi tentang kebutuhan-kebutuhan yang 
diperlukan dalam menunjang kegiatan pembelajaran kimia terutama pada aspek guru, siswa, bahan ajar, model dan sarana pembelajaran lainnya.

Subyek dalam uji lapangan operasional adalah siswa kelas X SMK Batur Jaya I Ceper. Sampel yang digunakan untuk uji berjumlah dua kelas dari 3 kelas $\mathrm{X}$ TPM. Sampel terdiri dari satu kelas pengguna dan satu kela kontrol yang dipilih secara teknik random sampling dengan didahului uji prasyarat pengambilan sampel (uji keseimbangan). Jumlah sampel telah sesuai dengan jumlah sampel uji lapangan menurut Suparman (2012) yaitu paling tidak sebanyak $15-30$ orang. Data yang diperoleh dari uji lapangan operasional berupa data kualitatif dan data kuantitatif. Data kualitatif terdiri dari data keterlaksanaan sintaks implementasi modul berbasis inkuiri terbimbing serta tanggapan guru dan siswa. Data kualitatif terdiri dari data hasil belajar siswa.

Untuk bisa mengetahui apakah validitas isi memenuhi syarat atau tidak, digunakan formula Aiken. Formula ini sebagai alat ukur yang digunakan untuk mengetahui validitas isi secara keseluruhan. Pada penelitian ini, jumlah penilai (reter) sebanyak tujuh (7) orang panelis untuk memeriksa kecocokan antara indikator dengan butir-butir instrumen, dalam bentuk menilai dari skala penilaian 1 sampai 4 dari masing-masing dari indikator.Untuk mencari reliabilitas soal bentuk obyektif digunakan rumus Kuder Richardson, yaitu KR-21.

Teknik analisis data yang digunakan dalam penelitian ini ialah dengan menganalisis data secara deskriptif kualitatif. Analisis digunakan untuk menyajikan informasi tentang data penelitian yang meliputi analisis kebutuhan, kelayakan produk dari para validator, respon siswa dan guru, kegiatan pembelajaran dan keterlaksanaan sintaks, serta data tes hasil belajar (post test), keterampilan, dan sikap siswa. Analisis data secara deskriptif kualitatif yaitu menguraikan serta menginterpretasikan data yang diperoleh dilapangan dari nara sumber. Analisis data ini didasarkan pada kemampuan nalar dalam menghubungkan fakta, data dan informasi sehingga diharapkan muncul gambaran yang dapat mengungkapkan permasalahan peneliti.

\section{Hasil Penelitian dan Pembahasan}

\section{Pengembangan Produk Modul Kimia Berbasis Inkuiri Terbimbing yang disertai Al-Qur'an dan Hadits}

Pengembangan produk modul kimia berbasis inkuiri yang disertai dengan ayat-ayat Al-Qur'an dan Hadits pada materi reduksi oksidasi dikembangkan sesuai dengan prosedur pengembangan Borg dan Gall (1983) yang dimodifikasi menjadi sembilan tahapan. Analisis kebutuhan merupakan bagian terpenting sebelum dilakukannya pengembangan modul. Tahapan pertama melakukan penelitian dan pengumpulan informasi yang didalam terdiri dari analisis studi literatur, studi lapangan dan studi kurikulum.

Sejalan dengan Sudjana, bahwa hasil belajar merupakan capaian akhir dari suatu proses pembelajaran yang dinilai dari kegiatan evaluasi (Sudjana, 2010). Dari hasil analisis 8 SNP seperti pada Tabel 4.1, observasi berupa angket kebutuhan guru pada Tabel 4.3 dan 4.4 dan wawancara didapatkan bahwa guru memerlukan suatu bahan ajar dan suatu model pembelajaran yang tepat sehingga dapat membantu proses pembelajaran agar siswa lebih mandiri, dan kreatif dalam berfikir. Modul merupakan solusi karena modul merupakan salah satu bahan ajar yang dikemas secara utuh dan sistematis, yang didalamnya memuat tentang pengalaman belajar yang terencana dan didesain agar siswa dapat menggunakannya secara mandiri (Depdiknas, 2008; Andi Prastowo, 2010). Model dalam modul tersebut adalah inkuiri terbimbing, pemilihan model tersebut mengacu pada 3 hasil penelitian yang menunjukkan bahwa pembelajaran inkuiri dapat meningkatkan pemahaman sains, produktivitas dalam berfikir kreatif, siswa 
lebih terampil dalam memperoleh dan menganalisis informasi, dan dapat meningkatkan prestasi belajar (Schlernker cit Trianto, 2009; Ifeoma, 2013).

Berdasarkan hasil wawancara guru, materi yang sulit untuk dipahami oleh siswa adalah pada materi reduksi-oksidasi. Hal ini disebabkan bilangan oksidasi yang sulit untuk dihafal dan dipahami oleh siswa. Pemilihan model inkuiri terbimbing pada materi reduksi oksidasi cukup tepat dikarenakan model inkuiri memungkinkan siswa yang memiliki kemampuan rendah untuk dapat berpartisipasi aktif dalam pembelajaran. Hal ini sejalan dengan hasil penelitian Sukroni (2013) yang menunjukkan bahwa siswa yang memiliki tingkat kemampuan rendah pada materi reduksi-oksidasi sangat tepat bila menggunakan model pembelajaran inkuiri terbimbing (Sukroni, 2013)

Selanjutnya, berangkat dari analisis studi kurikulum baik pada kompetensi inti (KI) dan Kompetensi dasar (KD) menunjukkan bahwa didalam pelaksanaan pembelajaran masih menggunakan pendekatan yang bersifat teacher centered padahal didalam kurikulum 2013 diharapkan siswa lebih berpartisipasi aktif. Selain lebih ditekankan pada pendekatan student centered, pada Kompetensi Dasar (KD) 1.1 dan Kompetensi Dasar (KD) 1.2 diharapkan siswa lebih menyadari akan kebesaran, kebenaran dan kekuasaan Tuhan YME. Selain itu, siswa juga diharapkan agar dapat lebih menyadari keteraturan dan keterkaitan antara ilmu sains dan ayat-ayat Al-Qur'an dan Hadits sehingga diharapkan dapat meningkatkan keimanan. Menurut Moh Roqib (2011) bukti dari keimanan adalah berbuat baik terhadap sesama (berakhlak mulia), hal ini sinergis dengan tujuan pendidikan nasional yaitu berkembangnya potensi peserta didik agar menjadi manusia yang beriman dan bertakwa kepada Tuhan Yang Maha Esa, berakhlak mulia, sehat, berilmu, cakap, kreatif, mandiri, dan menjadi warga negara yang demokratis serta bertanggung jawab.
Produk modul kimia berbasis inkuiri terbimbing pada materi reduksioksidasi dikembangkan dengan menggunakan sintak dari inkuiri terbimbing. Douglas (2009) dalam penelitiannya yang berjudul Process Oriented Guided Inquiry Learning in Engineering, disebutkan bahwa sintak inkuiri terbimbing terdiri dari orientasi, rumusan masalah, rumusan hipotesis, pengumpulan data, uji hipotesis, dan kesimpulan. Sedangkan dari sisi pengembangan modul yang memiliki keterkaitan antara ilmu sains dengan ayatayat Al-Qur'an dan Hadits dikembangkan dengan model informatif, yang artinya informasi mengenai materi reduksi oksidasi diperkaya dengan informasi adanya ayatayat Al-Qur'an dan Hadits yang masih saling berkaitan, Amin Abdullah (2006).

2. Kelayakan Modul Kimia Berbasis Inkuiri Terbimbing disertai ayat-ayat Al-Qur'an dan Hadits pada materi reduksi-oksidasi.

Kelayakan Modul Kimia Berbasis Inkuiri Terbimbing disertai ayat-ayat AlQur'an dan Hadits pada materi reduksioksidasi diuji melalui tahap validasi ahli, penilaian praktisi pendidikan, dan siswa sebagai kelompok uji coba awal, uji coba lapangan dan uji pelaksanaan lapangan. Hasil validasi 4 ahli dan 3 praktisi pendidikan menunjukkan bahwa modul sudah sesuai dengan yang dikembangkan dengan hasil kriteria memiliki kualitas sangat baik. Hal ini berdasarkan penilaian para ahli pengembangan modul, ahli materi, ahli bahasa, dan ahli media desain dan kegrafisan.

Namun, diperlukan beberapa perbaikan sesuai saran dari setiap ahli melalui revisi modul pertama.

Hasil penilaian guru dan siswa pada uji coba awal, penilaiannya meliputi aspek materi, bahasa dan media. Hasilnya menunjukkan bahwa modul tersebut termasuk kategori sangat baik menurut ratarata guru dan siswa. Namun, perlu adanya perbaikan sesuai saran yang diperoleh melalui revisi modul uji coba awal. Revisi 
modul uji coba awal yang dilakukan meliputi: a). Penambahan keterangan pengambilan ayat Al-Qur'an dan hadits pada setiap materi, b). Warna dan desain dibuat ulang tanpa merubah judul dan gambar, c). Cetakan gambar dan tulisan diperjelas.

Hasil penilaian guru dan siswa pada uji coba lapangan menunjukkan bahwa penilaian modul pada aspek materi, bahasa dan media menunjukkan bahwa modul tersebut termasuk kategori sangat baik menurut rata-rata guru dan siswa. Namun perlu adanya perbaikan sesuai saran yang diperoleh melalui revisi modul uji coba lapangan.

Hasil penilaian guru dan siswa pada uji pelaksanaan lapangan menunjukkan bahwa penilaian pada aspek materi, bahasa dan media menunjukkan bahwa modul tersebut termasuk kategori sangat baik menurut rata-rata guru dan siswa. Namun, diperlukan perbaikan sesuai saran yang diperoleh melalui revisi modul uji pelaksanaan lapangan. Dari uji lapangan operasioanl tidak ada revisi karena guru dan siswa memberikan masukan yang sama dengan sebelumnya yaitu perlu adanya penambahan gambar, tetapi karena gambar sudah ada dan pada intinya sama. Sehingga dalam uji pelaksanaan lapangan tidak ada penambahan gambar atau revisi.

3. Efektifitas Modul kimia berbasis inkuiri terbimbing disertai ayat-ayat Al-Qur'an dan Hadits pada materi reduksi-oksidasi. Pada analisis Uji Efektivitas Penilaian Pengetahuan pada hasil uji Chi Kuadrat dua sampel menunjukkan bahwa modul kimia berbasis inkuiri terbimbing disertai ayat-ayat Al-qur'an dan Hadits pada materi reduksi-oksidasi efektif dalam memberdayakan hasil belajar siswa (dalam penelitian berupa posttest). Hasil uji Chi Kuadrat dua sampel menghasilkan keputusan uji berupa penolakan Ho karena memiliki sig sebesar 0,010 $(<0,05)$ sehingga disimpulkan bahwa terdapat perbedaan hasil posttest antara kelas pengguna modul kimia berbasis inkuiri terbimbing dengan kelas kontrol yang menggunakan LKS (Lembar Kerja Siswa).

Efektifitas modul kimia berbasis inkuiri terbimbing pada materi reduksioksidasi ditunjukkan pula oleh perbedaan rata-rata posttest pada kelas pengguna modul memiliki tingkat perbedaan 6.07 yang lebih tinggi dibanding dengan kelas kontrol. Rata-rata kelas pengguna adalah 43,75, sedangkan rata-rata kelas kontrol adalah 37,68. Melihat hasil rata-rata tersebut masih banyak siswa yang belum memenuhi nilai KKM dalam materi reduksi-oksidasi akan tetapi memiliki perbedaan yang signifikan 6.07 dari kelas kontrol maka penggunaan modul berbasis inkuiri ini dapat dikatakan efektif dan dapat meningkatkan hasil belajar jika digunakan dalam pembelajaran. Hal ini dikarenakan dalam proses pembelajaran, siswa diarahkan pada menemukan konsep secara langsung sehingga pengalaman yang diperoleh daya ingatnya akan lebih lama dan siswa lebih mudah memahami materi yang sedang dipelajari. Berdasarkan hasil uji Chi Kuadrat dua sampel, disimpulkan bahwa model inkuiri terbimbing sangat efektif dalam memberdayakan hasil belajar siswa. Hasil ini sesuai dengan penelitian Nuangchalerm (2014) dengan pembelajaran inkuiri, dimana siswa memiliki rasa ingin tahu secara alami, dan rasa ingin belajar, sehingga berdampak positif bagi keaktifan siswa.

Pada Uji Efektivitas Penilaian Sikap, analisis uji efektifitas dari penilaian sikap terhadap penggunaan modul pada uji Chi Kuadrat pada aspek rasa syukur materi perkembangan redoks menghasilkan keputusan uji berupa penolakan Ho karena memiliki sig sebesar $0,006 \quad(<0,05)$ sehingga disimpulkan bahwa terdapat perbedaan sikap rasa syukur antara kelas pengguna modul kimia berbasis inkuiri terbimbing dengan kelas kontrol yang menggunakan LKS (Lembar Kerja Siswa), dan aspek rasa syukur materi bilangan oksidasi dan materi tatanama senyawa menghasilkan keputusan uji yang sama berupa penerimaan Ho karena pada 
bilangan oksidasi memiliki signifikansi sebesar 0,367 $(>0,05)$ dan pada tatanama senyawa memiliki sig. sebesar 0,037 (> $0,05)$ sehingga disimpulkan bahwa tidak terdapat perbedaan sikap rasa syukur antara kelas pengguna modul kimia berbasis inkuiri terbimbing dengan kelas kontrol yang menggunakan LKS (Lembar Kerja Siswa).

Uji efektifitas pada uji Chi Kuadrat pada aspek kejujuran materi perkembangan redoks dan bilangan oksidasi menghasilkan keputusan uji yang sama berupa penerimaan Ho karena memiliki sig sebesar $0,390(>0,05)$ dan $0,362(>0,05)$ sehingga disimpulkan bahwa tidak terdapat perbedaan sikap jujur antara kelas pengguna modul kimia berbasis inkuiri terbimbing dengan kelas kontrol yang menggunakan LKS (Lembar Kerja Siswa), dan aspek kejujuran pada materi tata nama senyawa menghasilkan keputusan uji berupa penolakan Ho karena pada materi tatanama senyawa memiliki sig. sebesar $0,000 \quad(<0,05)$ sehingga disimpulkan bahwa terdapat perbedaan sikap jujur antara kelas pengguna modul kimia berbasis inkuiri terbimbing dengan kelas kontrol yang menggunakan LKS (Lembar Kerja Siswa).

Uji efektifitas pada uji Chi Kuadrat pada aspek toleransi materi perkembangan redoks dan bilangan oksidasi menghasilkan keputusan uji yang berupa penerimaan Ho karena memiliki sig sebesar 0,956 (> 0,05) sehingga disimpulkan bahwa tidak terdapat perbedaan sikap toleransi antara kelas pengguna modul kimia berbasis inkuiri terbimbing dengan kelas kontrol yang menggunakan LKS (Lembar Kerja Siswa), dan aspek toleransi pada materi bilangan oksidasi dan materi tata nama senyawa menghasilkan keputusan uji berupa penolakan Ho karena pada bilangan oksidasi memiliki sig. sebesar 0,001 (< $0,05)$ dan pada materi tata nama senyawa memiliki sig. sebesar 0,012 $(<0,05)$ sehingga disimpulkan bahwa terdapat perbedaan sikap toleransi antara kelas pengguna modul kimia berbasis inkuiri terbimbing dengan kelas kontrol yang menggunakan LKS (Lembar Kerja Siswa)

Uji efektifitas pada uji Chi Kuadrat aspek bekerja keras pada ketiga materi yaitu perkembangan redoks, bilangan oksidasi dan tatanama senyawa menghasilkan keputusan uji yang sama berupa penolakan Ho karena memiliki sig masing-masing sebesar 0,004 $(<0,05), 0,002(<0,05)$ dan $0,000(<0,05)$ sehingga disimpulkan bahwa ketiga materi terdapat perbedaan sikap kerja keras antara kelas pengguna modul kimia berbasis inkuiri terbimbing dengan kelas kontrol yang menggunakan LKS (Lembar Kerja Siswa).

Uji efektifitas pada uji Chi Kuadrat aspek sikap bertanggung jawab pada materi yaitu perkembangan redoks, menghasilkan keputusan uji berupa penerimaan Ho karena memiliki sig sebesar 0,170 $(>0,05)$ sehingga disimpulkan bahwa tidak terdapat perbedaan sikap bertanggung jawab antara kelas pengguna modul kimia berbasis inkuiri terbimbing dengan kelas kontrol yang menggunakan LKS (Lembar Kerja Siswa). Sedangkan pada materi bilangan oksidasi dan tatanama senyawa menghasilkan keputusan uji yang sama berupa penolakan Ho karena masingmasing memiliki sig sebesar $0,016(<0,05)$ dan 0,006 $(<0,05)$ sehingga disimpulkan bahwa terdapat perbedaan sikap bertanggung jawab antara kelas pengguna modul kimia berbasis inkuiri terbimbing dengan kelas kontrol yang menggunakan LKS (Lembar Kerja Siswa)

Berdasarkan hasil uji Chi Kuadrat dua sampel dan rata-rata nilai sikap, disimpulkan bahwa model inkuiri terbimbing tergolong efektif dalam memberdayakan sikap karakter siswa meskipun tidak dapat secara konsisten dalam peningkatan nilai karakter siswa hal ini disebabkan adanya latar belakang lingkungan yang berbeda dan untuk penilaian karakter perlu jangka yang relatif lama hal ini dikarenakan sifat manusia tidak dapat di nilai dalam waktu yang relatif singkat. Hasil ini sesuai dengan penelitian Nancy G. Harrington (2013) bahwa dalam 
pendidikan karakter di sekolah tidak berpengaruh secara konsisten pada perilaku siswa di situasi yang berbeda. Begitu juga pada hasil penelitian Gary Skaggs dan Nancy Bodenhorn (2006) yang menunjukkan pendidikan karakter tidak berpengaruh signifikan terhadap prestasi belajar siswa oleh karena proses pendidikan karakter tidak hanya dilakukan oleh guru tetapi lingkungan sekitar siswa juga ikut berperan.

Pada uji efektivitas penilaian keterampilan, analisis uji efektifitas dari penilaian ketrampilan terhadap penggunaan modul pada uji Chi Kuadrat materi perkembangan redoks dan bilangan oksidasi menghasilkan keputusan uji berupa penolakan Ho karena masing-masing memiliki sig sebesar 0,008 dan 0,018 (< $0,05)$ sehingga disimpulkan bahwa terdapat perbedaan ketrampilan antara kelas pengguna modul kimia berbasis inkuiri terbimbing dengan kelas kontrol yang menggunakan LKS (Lembar Kerja Siswa). Sedangkan pada materi tatanama senyawa memiliki sig sebesar 0,241 $(>0,05)$ sehingga disimpulkan bahwa tidak terdapat perbedaan ketrampilan antara kelas pengguna modul kimia berbasis inkuiri terbimbing dengan kelas kontrol yang menggunakan LKS (Lembar Kerja Siswa).

Berdasarkan hasil uji Chi Kuadrat dua sampel dan rata-rata nilai ketrampilan, disimpulkan bahwa model inkuiri terbimbing tergolong efektif meskipun dalam rata-rata nilai materi perkembangan redoks dan tatanama senyawa mengalami penurunan hal ini disebabkan siswa belum terbiasa dengan model pembelajaran yang bersifat students centered sehingga ada beberapa kegiatan yang belum dapat dilakukan secara mandiri dan menyeluruh. Akan tetapi jika model inkuiri terbimbing ini ada tindak lanjut untuk dilakukan secara terus menerus siswa akan terbiasa dengan model yang sedang diterapkan selama proses pembelajaran.

\section{Kesimpulan dan Rekomendasi}

\section{Kesimpulan}

Berdasarkan analisis yang telah dipaparkan pada bab sebelumnya, maka dapat disimpulkan sebagai berikut: Pertama, Pengembangan modul kimia berbasis inkuiri terbimbing yang disertai ayat-ayat Al-Qur'an dan Hadits dilakukan dengan menggunakan langkah pengembangan yang kemukakan oleh Borg \& Gall (1983) sampai pada tahap ke sembilan.

Kedua, Pengembangan modul kimia berbasis inkuiri terbimbing yang disertai ayat-ayat Al-Qur'an dan Hadits dapat dikatakan "sangat baik" ditinjau dari aspek materi 96,42\%, media 92,41\%, bahasa 96,64\% dan kegrafisan 98,08\%. Persentase tersebut didapatkan berdasarkan penilaian dari para validator, sehingga dapat disimpulkan bahwa modul yang dikembangkan dikatakan "sangat baik"untuk digunakan dalam pembelajaran kimia.

Ketiga, Pengembangan modul kimia berbasis inkuiri terbimbing yang disertai ayat-ayat Al-Qur'an dan Hadits yang dikembangkan efektif digunakan untuk meningkatkan hasil belajar para siswa. Hal tersebut dilihat dari hasil uji efektifitas sebesar 0,010 yang mana lebih rendah dari taraf signifikasi $\alpha=0,05$ sehingga dapat disimpulkan bahwa hasil belajar menggunakan modul kimia berbasis inkuiri terbimbing lebih baik dari pembelajaran konvensional.

\section{Rekomendasi}

Bagi Guru, hendaknya memahami metode inkuiri terbimbing pada modul yang akan digunakan dalam proses pembelajaran. Bagi peneliti selanjutnya, agar lebih memperbanyak contoh-contoh keterkaitan antara materi redoks dengan ayat-ayat AlQur'an dan hadits. Selain itu, peneliti selanjutnya diharapkan agar mengembangkan materi-materi lain yang masih berhubung kait dengan ayat-ayat AlQur'an dan hadits. 
Terakhir, bagi siswa. Hendaknya para siswa tidak menggantungkan guru sebagai pusat pembelajaran di kelas. Selain itu, siswa diharapkan menggali lebih dalam materi-materi yang sedang dipelajari. Semoga dengan adanya materi yang dikaitkan dengan ayat-ayat Al-Qur'an dan hadits.

\section{Daftar Pustaka}

Abdullah, Amin. 2006. Kerangka Dasar Keilmuan dan Pengembangan Kurikulum. Yogyakarta: UIN Sunan Kalijaga.

2006. Islamic Studies di Perguruan Tinggi: Pendekatan IntegratifInterkonektif. Yogyakarta: Pustaka Pelajar.

Abdullah, S.R. 2014. Sains Berbasis Al-Qur'an. Jakarta: Bumi Aksara

Aiken, L.R. 1985. Three Coefficients for Analyzing the Reliability and Validity of Ratings. Educational and Psychological Measurement, 45: 131142

Alias, N dan Saedah S. 2012.Design and Development of Physics Module Based on Learning Style and Appropriate Technology by Employing Isman Instructional Design Model. TOJET: The Turkish Online Journal of Educational Technology. 11(4): 84-93.

Anderson, L.W dkk. 2010. Kerangka Landasan untuk Pembelajaran, Pengajaran dan Assesmen. Yogyakarta: Pustaka pelajar.

Aunurrahman. 2009. Belajar dan Pembelajaran. Bandung: Alfabeta.

Brady, J.E. 1998. Kimia Universitas Azas \& Struktur. Penerjemah: Maun, S. dkk. Jakarta: Binarupa Aksara.

Borg, W.R. dan Gall, M.D. 1983. Educational Research An Introduction. New York: Longman.

Carin, A.A. dan Sund, R.B. 1989. Teaching Science Throught Discovery. Colombus, Ohio: Merril Publishing Company.
Dahar, R.W. 2006. Teori-teori Belajar dan Pembelajaran. Jakarta: Erlangga.

Hamid, D. 2011. Metode Penelitian Pendidikan. Bandung: Alfabeta.

Douglas, E.P. \& Chu, C.C. 2012. ProcessOriented Guided Inquiry Learning in Engineering. Procedia - Social Behavioral Sciences 56(2): 253-257.

Depdiknas. 2008. Teknik Penyusunan Modul. Jakarta: Direktorat Jenderal Manajemen Pendidikan Dasar dan Menengah, Departemen Pendidikan Nasional.

. 2008. Kamus Besar Bahasa Indonesia Pusat Bahasa. Jakarta: PT. Gramedia Pustaka Utama.

Eggen, P. \& Kauchak, D. 2012. Strategi dan Model Pembelajaran Mengajarkan Konten dan Keterampilan Berpikir. Penerjemah: Satrio Wahono. Jakarta: PT Indeks.

Skaggs, G and Bodenhorn, N. (2006). Relationships Between Implementing Character Education, Student Behavior, and Student Achievement. Journal of Advanced Academics. 18 (2): 82-116.

Gerald, L.F. 2011. The Twin Purposes of Guided Inquiry: Guiding Student Inquiry and Evidence Based Practice. 30 (1): $26-41$

Guilford, J.P. (1956). Fundamental Statistics in Psychology and Education. New York: McGraw Hill.

Hamalik, O. 2003. Proses Belajar Mengajar. Jakarta: BumiAksara.

Hamdani. 2011. Strategi Belajar Mengajar. Bandung: Pustaka Setia

Hendi , R.R. 2010. Tesis. Pembelajaran Berbasis Inkuiri Terbimbing dengan Multimedia dan Lingkungan Riil di tinjau dari Morivasi Berprestasi dan Kemampuan Awal. Surakarta: Program Pascasarjana UNS.

Hudaya, Latuconsina. 2014. Pendidikan Kreatif. Jakarta: PT Gramedia Pustaka Utama.

Hungerford, H.R., Volk, T.L., dan Ramyes, J.M. 1990. Science-Technology-Society: Investigating and Evalualiting STS 
Issues and Soluton. Illinois: STIPES Publishng Co.

http://www.skornews.com/skor-icw-2014kasus-korupsi-meningkat.html, di akses pada tanggal 25 maret 2015

Ifeoma, O.E dan Ezeoba, K.O. 2013. Effects of Guided Inquiry Method on Secondary School Students Performance in Social Studies Curriculum in Anambra State, Nigeria. British Journal of Education, Society \& Behavioural Science. 3(3): 206-222.

Johnson, B.R. Siegler, R.S dan Alibali, M.W. 2001. Developing Conceptual Understanding and Procedural Skill in Mathematics: An Iterative Process. Journal of Educational Psychology. 93(2): 346-362.

Karem, A.H.A., Kamisah, O. \& Subahan, M.M. 2011. The Impact of Module Based Curriculum and Extra-Curriculum Activities in Developing Envronmental Skills Among Saudi's Secondary Student. Procedia Social and Behavioral Sciences 15(2): 1756 1760.

Maher, A. 2004. Learning Outcomes in Hinger Education: Implications for Curriculum Design and student Learning. Journal of Hospitality, Leisure, Sport and Tourism Education. 3(2): 46-54

Muh. Surya. 1981. Pengantar Psikologi Pendidikan. Bandung: FIP-IKIPBandung

Mulyasa, E. H. (2013). Pengembangan dan Implementasi Kurikulum 2013. Bandung: Remaja Rosdakarya.

Munzenmaier, C. dan Rubin, N. 2013. Bloom's Taxonomy: What's Old is New Again. Santa Rosa: The Elearning Guild Research.

Nanang, H dkk. (2012). Konsep Strategi Pembelajaran. Bandung: PT Refika Aditama.

Harrington, N.G. (2010). Evaluation of the All Stars Character Education and Problem Behavior Prevention Program: Mediator and Outcome Variables for Middle School Students. Journal of
Health Education \& Behavior.28 (5): 533-546.

Nasri, Saipun. 2011. Hubungan Antara Persepsi Pengguna Modul Kompendium AlQur'an dengan Metode Diskusi, Kemampuan Awal dan Motivasi Belajar dengan Prestasi Belajar Biologi Siswa. Tesis. Surakarta: Program Pascasarjana Universitas Sebelas Maret.

Nasution, S. 2003. Berbagai Pendekatan dalam Proses Belajar \& Mengajar. Jakarta: Bumi Aksara.

Nuangchalerm, P. 2014. Inquiry Based Learning in China: Lesson Learned for School Science Practices. Asian Social Science. 10(13): 95-110.

Pintrich, P.R. 2002. The Role of Metacognitive Knowledge in Learning, Teaching and Assessing. Theory into Practice. 41(4): 219-225

Prastowo, A. 2012. Panduan Kreatif Membuat Bahan Ajar Inovatif. Yogyakarta: Diva Press.

Pritchard, A. and Woollard, J. 2010. Psychology for the Classroom: Constructivism and Social Learning. New York: Routledge.

Riduwan. 2008. Skala Pengukuran Variabelvariabel Penelitian. Bandung: Alfabeta

Roqib, Moh. 2011. Prophetic Education. Purwokerto: STAIN Press

Salam, A., Sutarto \& Wicaksono, D.D. 2013. Ensiklopedia Kimia 2. Jakarta: PT Lentera Abadi.

Sanjaya, W. 2006. Strategi Pembelajaran Berorientasi Standar Proses Pendidikan. Jakarta: Kencana Predana Media Group.

Sakroni. 2013. Pengaruh Model Pembelajaran Berbasis Masalah dan Inkuiri Terbimbing Terhadap Prestasi Belajar Ditinjau dari Tingkat Kemampuan Berpikir dan Tingkat Kemandirian Siswa. Tesis. Surakarta: Program Pascasarjana Universitas Sebelas Maret.

Shihab, Quraish M. 1994. Membumikan AlQur'an: Fungsi dan Peran Wahyu 
dalam Kehidupan Masyarakat. Bandung: Mizan

Schunk, D.H. 2012. Learning Theories an Educational Perspective (Teori-teori pembelajaran Perspektif Pendidikan). Yogyakarta: Pustaka Pelajar.

Slameto, 1998.Belajar dan Faktor-faktor yang Mempengaruhinya. Jakarta: Rineka Cipta.

Star, J.R dan Stylianides, G.J. 2013. Prosedural and Conceptual Knowledge: Exploring the Gap Between Knowledge Type and Knowledge Quality. Canadian Journal of Science, Mathematics and Technology. 13(2): 169-181.

Sudijono, Anas. 2008. Pengantar Evaluasi Pendidikan. Jakarta: Raja Grafindo.

Sudjana, N. 2010. Penilaian Hasil Proses Belajar Mengajar. Bandung: Remaja Rosdakarya.

Suharsimi, Arikunto. 2006. Prosedur Penelitian Suatu Pendekatan Praktik. Jakarta: Rineka Cipta.

Sungkono. (2003). Pengembangan Bahan Ajar. Yogyakarta: Diva Pres.

Suparman, A. 2012. Desain Instruksional Modern. Jakarta: Erlangga.

Suwastono. 2011. Pengembangan Pembelajaran E-Learning Berbasis Moodle pada Mata Kuliah Penginderaan Jauh S-1 Jurusan Geografi Universitas Negeri Malang. Tesis. Malang: PPS UM Malang.

Kiong, T.T. (2011). The Development And Evaluation of the Qualities of Buzan Mid Mapping Module. Procedia-Social and Behavioral Sciences. Faculty of Vocational Education. Universiti Tun Hussein Onn Malaysia.

Trianto. 2009. Mendesain Model Pembelajaran Inovatif

progresif: $\quad$ Konsep Landasan Implementasi pada KTSP. Jakarta: Prenada Media Group

1993. Psikologi Pendidikan. Bandung: FIP-IKIP-Bandung

Yamin, M. 2013. Paradigma Baru Pembelajaran. Jakarta: Referensi Ciputat Mega Mall.
Vessel, M.F. 1965. Elementary School Science Teaching. New Dehli: Prentice-Hall of India, Ltd.

Vlassi, M \& Alexandra, K. 2013.The comparison between guided inquiry and traditional teaching method. A case study for the teaching of the structure of matter to 8-sth grade greek students. Procedia - Social Behavioral Sciences. 93(3):

494-497. 